\title{
Mature intracranial teratoma with meningocele in a lamb
}

\author{
Marcus Vinicius Lima Nunes ${ }^{1}$ (i) Karen Yumi Ribeiro Nakagaki ${ }^{2}$ (i) \\ Débora Nunes Procópio Miranda ${ }^{1}$ Lucas Emanuel dos Santos Mesquita ${ }^{1}$ (B)

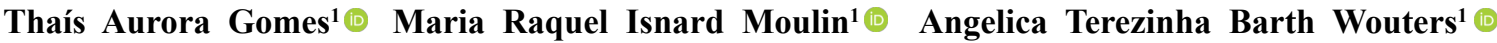

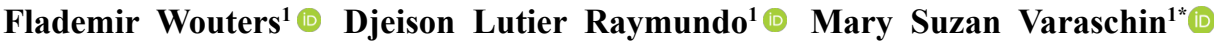

\footnotetext{
${ }^{1}$ Departamento de Medicina Veterinária, Faculdade de Ciência Animal, Universidade Federal de Lavras (UFLA), 37200-900, Lavras, MG, Brasil. E-mail: msvaraschin@ufla.br. "Corresponding author.

${ }^{2}$ Programa de Pós-graduação em Patologia, Universidade Federal de Minas Gerais (UFMG), Belo Horizonte, MG, Brasil.

ABSTRACT: This study described the pathological aspects of a mature intracranial teratoma with meningocele in a one-day-old lamb. The diagnosis of mature teratoma was based on microscopic features, where well-differentiated tissues representative of the three germ layers were observed. The tumor consisted of respiratory, gastrointestinal and urinary epithelium as components of the endoderm; muscle and bone tissues as components of the mesoderm; and keratinized stratified squamous epithelium and adnexa as components of the ectoderm. To the best of our knowledge, this is the first report of intracranial teratoma with meningocele in animals.

Key words: intracranial teratoma, meningocele, Lamb.
}

Teratoma intracraniano benigno com meningocele em um cordeiro

RESUMO: Descrevem-se os aspectos patológicos de um teratoma intracraniano benigno com meningocele em um cordeiro de um dia de idade. $O$ diagnóstico de teratoma benigno foi baseado nos achados histopatológicos, com tecidos representativos das três camadas germinativas. $O$ tumor consistia de epitélio respiratório, gastrintestinal e urinário como componentes do endoderma; tecido muscular e ósseo do mesoderma; e epitélio escamoso estratificado queratinizado e anexos como componentes do ectoderma. Com base no conhecimento dos autores, este é o primeiro relato de teratoma intracraniano com meningocele em animais.

Palavras-chave: teratoma intracranial, meningocele, cordeiro.

Teratomas are tumors that contain cellular components derived from at least two of the three embryonic germ layers (REINDEL et al., 1996). They probably arise from pluripotential germ cells that have undergone differentiation (AGNEW \& MAcLACHLAN, 2017). Teratomas in humans account for approximately $0.5-1 \%$ of primary adult intracranial tumors, with a higher frequency in children $(\sim 7 \%)$ and are more common in the pineal region, suprasellar cistern, basal ganglia, and thalamus (ZYGOURAKIS et al., 2015).

In non-human mammals, intracranial teratomas have been reported in alpaca (HILL \& MIRAMS, 2008), cat (CHÉNIER et al., 1998), rat (REINDEL et al., 1996), dog (PATNAIK \&
NAFE, 1980), rabbit (BISHOP, 1978), sheep (DAMODARAN et al., 1978) and deer (HEADLEY et al., 2016), with younger animals being the most affected (CHÉNIER et al., 1998).

Histologically, teratomas can be classified as mature or immature tumors. A mature teratoma consists of the complete differentiation of the ectodermal, mesodermal and endodermal elements (COLPAN et al., 2004). Immature teratoma have more undifferentiated tissue consisting of embryonic mesodermal elements and neuroectodermal tissue and have a high mitotic index (HIGGINS et al., 2017).

Meningocele is a congenital anomaly in domestic animals characterized by the herniation of fluid-filled meninges through a defect in the cranium. 
Herniation is related to the suture lines, usually in the frontal region. It occurs from a focal failure of dehiscence of the neural tube from the embryonic ectoderm, accompanied by a focal failure of the development of the axial skeletal encasement (CANTILE \& YOUSSEF, 2016). In animals, meningocele has been reported in calves (LAPOINTE et al., 2000), lambs (KOHLI, 1998), foals (VAN HOOGMOED et al., 1999), pigs (CHO et al., 2015) and cats (CANTILE \& YOUSSEF, 2016).

The association of tumors in the central nervous system with defects of the neural tube is rare and has been reported in humans, such as in the association of an encephalocele and spinal teratoma (RADMANESH et al., 2007) and in the Currarino triad, a congenital disease characterized by sacral agenesis, anorectal malformations, and a presacral mass, which in most cases is a teratoma in the spinal cord (EMOTO et al., 2018). This report aimed to describe the pathological aspects of a mature intracranial teratoma with meningocele in a lamb.

A one-day-old male Santa Inês lamb was submitted to necropsy in the Veterinary Pathology Laboratory at the Universidade Federal de Lavras, Minas Gerais State, Brazil. At necropsy, a two-centimeter osseous defect (cranium bifidum), not covered by skin, in the dorsal region of the parietal bone with a $2.0 \times 2.5 \times 2.5 \mathrm{~cm}$ protrusion of fluid-filled meninges (meningocele) (Figure 1A) was found. A viscous fluid (Figure 1B) involving the leptomeninges from the meningocele to the cerebellum and brainstem region was observed. The cerebellum was laterally displaced, with flattening of the gyri and narrowing of the sulci, and on the right side, there was a firm whitish mass with an area of $3,0 \times 2.5 \mathrm{~cm}$ with hairs protruding on its surface (Figure 1C). The mass involved the colliculi, was impossible to distinguish between the caudal and rostral colliculi, and displaced the medulla oblongata laterally. The hairs were deeper in the brainstem and terminated in a cystic cavity filled with viscous fluid. Discrete bilateral enlargement of the lateral ventricles was also observed. Tissue samples were fixed in $10 \%$ neutral buffered formalin and routinely processed for histopathologic examination. Additional brain sections were submitted to alcian blue staining.

Microscopically, a pseudostratified columnar ciliated epithelium with goblet cells, associated with serous glands in the submucosa (Figure 2A), characterizing a typical respiratory epithelium, was observed. In other areas, osseous tissue forming trabecular bone was observed (Figure 2B). Adjacent to the respiratory epithelium, there was a keratinized stratified squamous epithelium (Figure 2C) associated with hair follicles and sweat and sebaceous glands. As a continuation of this epithelium, there was a stratified and nonkeratinized squamous epithelium, with mucous glands in the submucosa and two muscular layers (internal circular and external longitudinal) immediately below it, structures that resembled a segment of the esophagus. Additionally, there were areas with a transitional urinary epithelium, characterized by basal nuclei and a greater amount of apical cytoplasm in the outermost layer. In several regions,

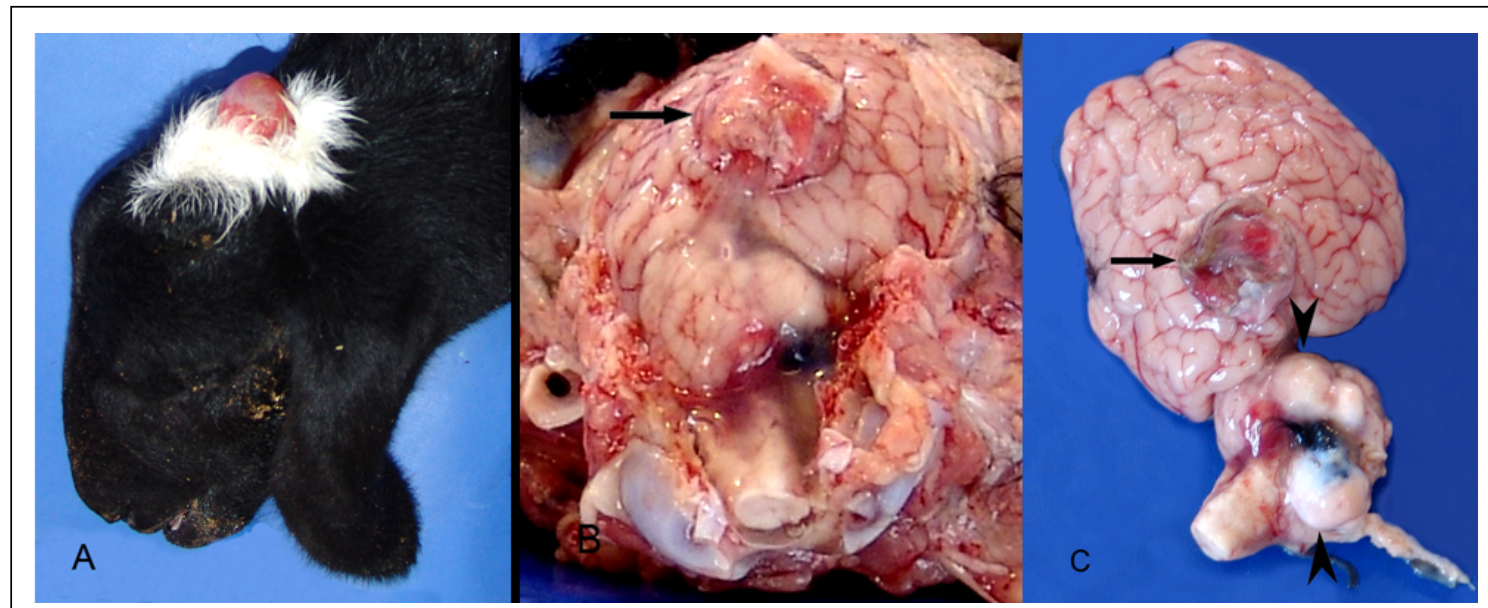

Figure 1 - Intracranial teratoma with meningocele in a lamb. (A) Cranium bifidum and meningocele. (B) Meningocele (arrow) and teratoma with a viscous fluid involving the leptomeninges. (C) Meningocele (arrow) and teratoma with black hairs (arrowhead) in the region of the cerebellum and brainstem. 


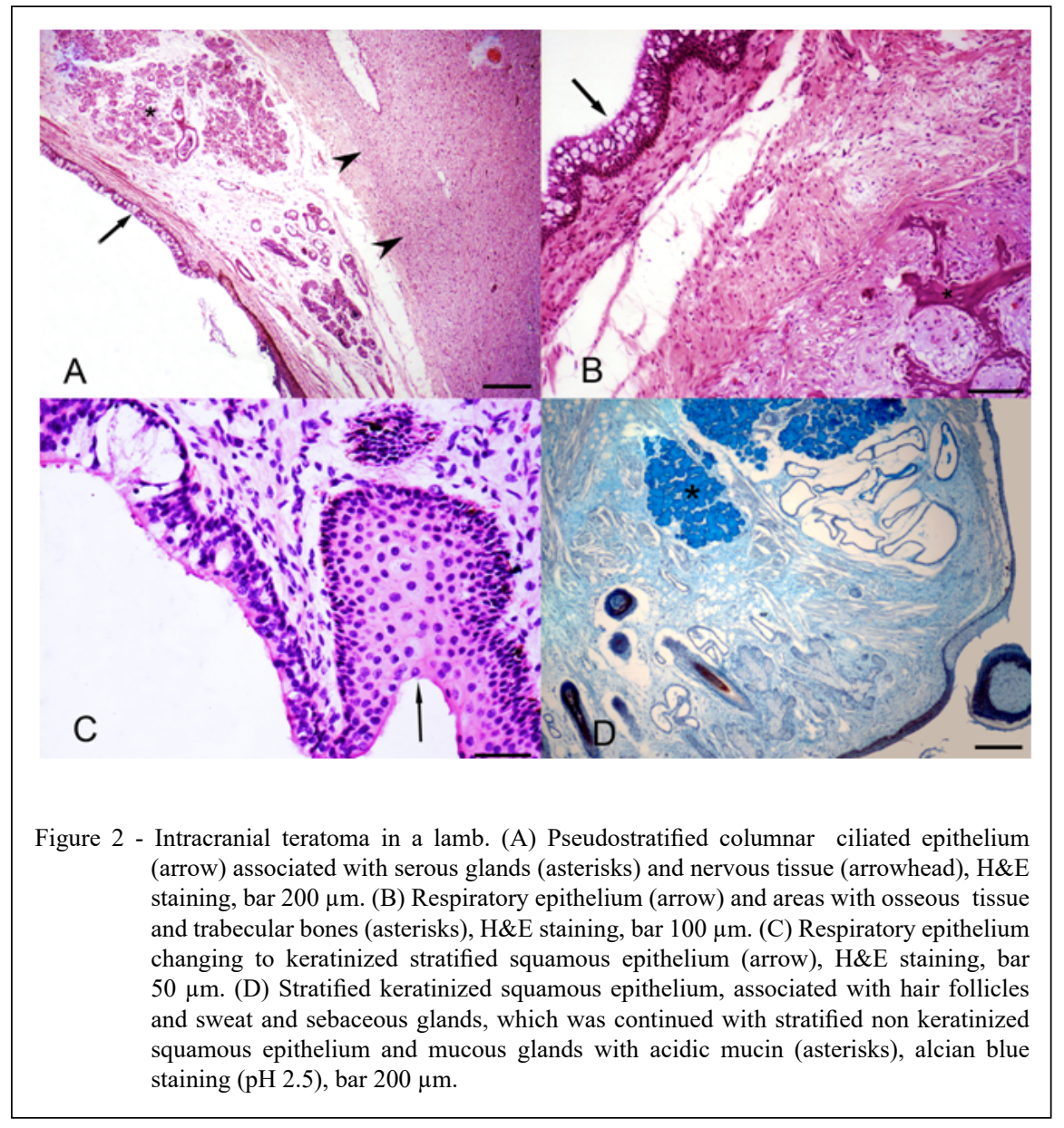

striated skeletal muscle and smooth muscle were observed. Alcian blue staining (pH 2.5) demonstrated acidic mucin in the cytoplasm of the serous glands, mucous glands, and goblet cells (Figure 2D).

The etiology and pathogenesis of extragonadal teratomas are still obscure. Some theories affirm that some embryonic germ cells do not reach the gonadal ridge and migrate aberrantly. These ectopic germ cells are generally incorporated into midline structures, which can be associated with the head, mediastinum or sacrococcygeal region. Lacking the signs of normal maturation, these ectopic germ cells conserve their pluripotential capacity and can develop into teratomas or any other type of germ cell neoplasm ( TAPPER \& LACK, 1984). The possibility of two different pathogeneses, one for teratoma and the other for meningocele, cannot be excluded. However, teratomas associated with defects of the neural tube are reported in humans (EMOTO et al., 2018, RADMANESH et al., 2007).
In the case described here, the diagnosis of mature intracranial teratoma was based on the microscopic findings of well-differentiated tissue originating from the three germ layers. Respiratory, esophageal and urinary epithelium represented the endoderm, bone and muscular tissue represented the mesoderm and the keratinized stratified squamous epithelium, associated with hair follicles and sweat and sebaceous glands, represented the ectoderm. These histological characteristics are consistent with those described in the literature (REINDEL et al., 1996; COLPAN et al., 2004). To the best of our knowledge, this is the first report of intracranial teratoma with meningocele in animals.

\section{ACKNOWLEDGEMENTS}

To Fundação de Amparo à Pesquisa do Estado de Minas Gerais (FAPEMIG) for financial support (Processo CVZPPM 00763-16), Coordenação de Aperfeiçoamento de Pessoal de Nivel Superior (Capes) for granting a master's scholarship (finance

Ciência Rural, v.50, n.12, 2020. 
code 001) and Conselho Nacional de Desenvolvimento Científico e Tecnológico (CNPq) for the Iniciação Científica (IC) grant.

\section{DECLARATION OF CONFLICT OF INTERESTS}

The authors declare no conflict of interest. The founding sponsors had no role in the design of the study; in the collection, analyses, or interpretation of data; in the writing of the manuscript, and in the decision to publish the results.

\section{AUTHORS' CONTRIBUTIONS}

The authors contributed equally to the manuscript.

\section{REFERENCES}

AGNEW, D. W.; MAcLACHLAN, J. N. Tumors of the genital system. In: MEUTEN, D .J. Tumor in Domestic Animals. Ames: John Wiley \& Sons Inc,, 2017. cap.16, p.689-722.

BISHOP, L. Intracranial teratoma in a domestic rabbit. Veterinary Pathology, v.15, n.4, p.525-530, 1978. Available from: <https:// journals.sagepub.com/doi/pdf/ 10.1177/030098587801500410>. Accessed: Feb. 18, 2020. doi: 10.1177/030098587801500410.

CANTILE, C; YOUSSEF, S. Nervous system. In: MAXIE, M.G. Jubb, Kennedy and Palmer's Pathology of Domestic Animals. St. Louis: Elsevier, 2016. v.1. cap.4. p.250-406.

CHÉNIER, S. et al. Intracranial teratoma and dermoid cyst in a kitten. Journal of Veterinary Diagnostic Investigation, v.10, n.4, p.381-384, 1998. Avaliable from: <https://journals.sagepub.com/ doi/pdf/10.1177/104063879801000417>. Accessed: Feb. 18, 2020 doi: $10.1177 / 104063879801000417$

CHO, I-Cetal. Two cases of meningocele and meningoencephalocele in Jeju native pigs. BMC Veterinary Research, v.11, p.89-92, 2015. Avaliable from: <https://bmcvetres.biomedcentral.com/ track/pdf/10.1186/s12917-015-0404-y>. Accessed: Jun. 15, 2020. doi: 10.1186/s12917-015-0404-y.

COLPAN, M. et al. Multilocated mature teratoma: a case report and review of the literature. Acta Neurochirurgica, v.146, n.10, p.1145-1150, 2004. Avaliable from: <https://link.springer.com/ article/10.1007/s00701-004-0314-4>. Accessed: Feb. 18, 2020. doi: 10.1007/s00701-004-0314-4.

DAMODARAN, S. et al. Teratoma of the brain in a sheep . Indian Veterinary Journal, v.65, p.579-580,1978. Not avaliable on line.

EMOTO, S. et al. Surgical management for a huge presacral teratoma and a meningocele in an adult with Currarino triad: a case report. Surgical Case Reports, v.4, n.1, p.9, 2018. Avaliable from: $<$ https://link.springer.com/article/10.1186/s40792-018-0419-2>. Accessed: Feb. 18, 2020. doi: 10.1186/s40792-018-0419-2.

HEADLEY, S. A. et al. Congenital mature intracranial teratoma in a Pampas deer (Ozotoceros bezoarticus) in Brazil. Journal of Wildlife Diseases, v.52, n.3, p.749-752, 2016. Avaliable fom: <https://www.jwildlifedis.org/doi/full/10.7589/2015-03-070>. Accessed: May, 15, 2020. doi: 10.7589/2015-03-070.

HIGGINS, R. J. et al. Tumors of the nervous system. In: MEUTEN, D.J. Tumor in Domestic Animals. Ames: John Wiley \& Sons Inc,, 2017. cap.19, p.834-891

HILL, F.; MIRAMS, C. Intracranial teratoma in an alpaca (Vicugna pacos) in New Zealand. The Veterinary Record, v.162, p.188189, 2008. Avaliable from: <https://veterinaryrecord.bmj.com/ content/162/6/188.short $>$. Accessed: Feb. 18, 2020. doi: 10.1136/ vr.162.6.188.

KOHLI, R. Congenital meningocele with a rare skull defect in a lamb. Australian Veterinary Journal, v.76, n.4, p.252, 1998. Avaliable from: <https://onlinelibrary.wiley.com/doi/ epdf/10.1111/j.1751-0813.1998.tb10151.x>. Acessed: Feb. 18, 2020. doi: 10.1111/j.1751-0813.1998.tb10151.x.

LAPOINTE, J.-M. et al. Tibial hemimelia, meningocele, and abdominal hernia in Shorthorn cattle. Veterinary Pathology, v.37, n.5, p.508-511, 2000. Avaliable from: <https://journals.sagepub. com/doi/pdf/10.1354/vp.37-5-508>. Accessed: Feb. 18, 2020. doi: $10.1354 /$ vp.37-5-508.

PATNAIK, A.; NAFE, L. Intracranial teratocarcinoma in a dog. Veterinary Pathology, v.17, n.6, p.764-769, 1980. Avaliable from: $<$ https://journals.sagepub.com/doi/pdf/10.1177/030098588001700 612>.Accessed: Feb. 18, 2020. doi: 10.1177/030098588001700612.

RADMANESH, F. et al. Teratoma within an encephalocele: common etiology or coincidence: Case report. Journal of Neurosurgery: Pediatrics, v.107, n.3, p.263-265, 2007. Avaliable from: $\quad<$ https://thejns.org/pediatrics/view/journals/j-neurosurgpediatr/107/3/article-p263.xml >. Accessed: Feb. 19, 2020. doi: 10.3171/PED-07/09/263.

REINDEL, J. et al. Malignant intracranial teratoma in a juvenile Wistar rat. Veterinary Pathology, v.33, n.4, p.462-465, 1996. Avaliable from: <https://journals.sagepub.com/doi/pdf/10.1 177/030098589603300421>. Accessed: Feb. 19, 2020. doi: $10.1177 / 030098589603300421$.

TAPPER, D.; LACK, E. E. Teratomas in infancy and childhood. A 54-year experience at the Children's Hospietal Medical Center. Annals of Surgery. v.198, p.398-410. 1983. Avaliable from: <https://journals.lww.com/annalsofsurgery/ Abstract/1983/09000/Teratomas_in_Infancy_and Childhood_A_54_Year.16.aspx>. Accessed: May 25, 2020. doi: $10.1097 / 00000658-198309000-00016$.

VAN HOOGMOED, L. et al. Surgical repair of a thoracic meningocele in a foal. Veterinary Surgery, v.28, n.6, p.496500, 1999. Avaliable from: <https://onlinelibrary.wiley.com/doi/ full/10.1111/j.1532-950X.1999.00496.x>. Accessed: Feb. 19, 2020. doi: 10.1111/j.1532-950X.1999.00496.x.

ZYGOURAKIS, C. C. et al. Management of central nervous system teratoma. Journal of Clinical Neuroscience, v.22, n.1, p.98-104, 2015. Avaliable from: <https://www.sciencedirect.com/ science/article/pii/S0967586814003749>. Acessed: Feb. 19, 2020. doi: 10.1016/j.jocn.2014.03.039. 